\title{
ECONOMIC INTELLIGENCE AND INTELLECTUAL CAPITAL IN AGRICULTURE COMPETITIVENESS - CASE STUDY
}

\author{
Slobodan Neškovićc , Žaklina Jovanović ${ }^{2}$,Miroslav Čavlin ${ }^{3}$
}

\begin{abstract}
Summary
The process of globalization in the last few decades conditioned the many technological, economic and social changes which have transformed the world market of agricultural products and the impact on the competitive environment. In the modern world, creating material value in agricultural production more and more the result of the intangible factors and production is increasingly based on knowledge, skills and innovation of employees. In the industrial age the necessary resources to achieve competitive advantages were capital, natural resources and work, while in today's knowledge-based economy the importance is on the information, innovation, knowledge, intellectual capital and intellectual property - that have become the foundation of creating all other values. These values are, because of their great importance in achieving the modern competitive advantages, very often the target of economic intelligence and therefore require all available forms of protection. The sector of agricultural production can make a significant contribution to improving the overall national competitiveness if it is based on intellectual capital as evidenced by the country with highly developed agriculture. However, by observing global changes can be concluded that Serbia in this sector has unused potential for growth and development.
\end{abstract}

Key words: competitiveness, intellectual capital, intellectual property, agricultural production, economic intelligence

JEL: $034, F 60, D 83, Q 17$

1 Slobodan Nešković Ph.D., Full Professor, University Business Academy, Faculty of Economics and Engineering Management, Novi Sad, Cvećarska street no. 2, 21000 Novi Sad, Serbia, Phone: +381 633916 59, E-mail: slobneskovic@gmail.com

2 Žaklina Jovanović M. A., Associate in Science Association Center for Strategic Research of National Security-CESNA B, Vojvode Vlahovića street no. 35đ/1.2, Belgrade, Serbia, +381 635313 93, E-mail: zaklinajovanovic.021@gmail.com

3 Miroslav Čavlin Ph.D., Associate Professor, University Business Academy in Novi Sad, FIMEK, Cvećarska street no. 2, 21000 Novi Sad, Serbia, Phone: +381 21400 484, E-mail: cmiros@gmail.com

EP 2016 (63) 2 (445-459) 


\section{Introduction}

The last decade of the twentieth century testifies that began a period of globalization, which is characterized by global competition, the standards of the world market and international orientation of organizations. In such a globalized environment, no company or country can't ignore the need to be competitive, because today only competition ensures survival. Material values are now more and more the result of intangible factors and the foundation of any successful agricultural production are specific knowledge, skills and innovation of employees. The manufacturing process is converted from working in the scientific process, which is the main characteristic of the new economy of the 21 st century.

For this reason this economy is called "knowledge economy". The strength, size and power companies in today's economy is characterized by the formation of intangible assets (knowledge and information) or more precisely - intellectual capital (Jovanović et al., 2010). The greater intellectual capital in the agricultural sector increases its ability to create some superior performance and value compared to the competition. Therefore, many countries with highly developed agriculture use own intellectual capital and intellectual property to improve its competitive position and increase profits. The most developed countries of the world are aware of the great importance of this capital and they are increasingly investing in intellectual resources, so the fight for global prestige transferred to the field of scientific and technological development. Intellectual capital in modern business conditions represents an extremely important resource and it is therefore very often the subject of economic intelligence. Economic espionage involves the activities of the individual institutions using which they are coming into the possession of knowledge and information in other countries that are used in science, technology and production. The most common targets of economic espionage are companies and countries that are at the top of developing new technologies and new knowledge in agricultural production. The ultimate goal is to get to business secrets, saving on the cost of research and development, as quickly as possible to make a profit, survive in the market and achieve competitive advantage.

It is indisputable that agricultural production in the modern world has a special significance for the stability of the overall economic development. However, in order to maximize the use of potentials of this sector is necessary to: 1.) take advantage of the positive characteristics of natural resources; 2.) take advantage of unused resources (available knowledge in the agricultural sector); 3.) implement the relevant competitive strategy in the sphere of agriculture through the permanent investment in intellectual capital. In addition to changes and innovation "visible" resources (in the domain of engineering and technology), it is very important and constantly develop, improve and implement the so-called. "invisible" resources (knowledge, education, science and research and development work). This is the only way to positively change the profile of agriculture and to achieve competitive position in the global market.

\section{Methodology and data sources}

The main problem of this study is the study of the process of globalization, intellectual capital 
and intellectual property as unavoidable factors and sources of competitive advantage in the modern "knowledge economy", as well as the issue of endangerment and protection of these very important resources.

The subject of this research is conjunctive relationship between the process of globalization, technological innovation, intellectual capital, intellectual property and their protection and the creation and maintenance of competitive advantages of agricultural production in the modern world.

The goal of this study is to show the direct correlation and conditionality of the competitiveness of agriculture, intellectual capital, innovation and properly protected intellectual property rights.

The purpose of this paper is to point to importance of intellectual capital, innovation and protected intellectual property in achieving competitive advantages in the sphere of agricultural production in the globalized market conditions and problems that may arise if these resources are not managed strategically.

The importance of intellectual capital to prove facts in practice, which confirm that the companies and countries that encourage and protect this important source of competitiveness today among the strongest in the world (Jovanović et al., 2011). Without these resources, today it is almost impossible to achieve and sustain a competitive advantage in a highly globalized business environment.

The basic hypothesis which we will try to prove is that achieving a competitive advantage in the modern world is completely determined by the process of globalization, strategic management and protection of intellectual capital. In accordance with the problem, the research objectives and the available information formulated the following hypotheses, which read:

\section{The main hypothesis:}

H1 - Countries that own the resources of intellectual capital and intellectual property, strategically manage to these resources and protect them adequately achieve global competitive advantage.

\section{Auxiliary hypothesis:}

$\mathbf{H 2}$ - Efficient and effective competitive strategy of agricultural production must involve intellectual capital and intellectual property protection.

H3 - Country which owns the quantity and / or quality in terms of specific knowledge or patent in agricultural production has a great competitive advantage compared to the competition. 


\section{Intellectual capital, intellectual property and "Knowledge economy"}

Modern globalization brought with it a many changes in various areas. Thanks to new technology, communication and new economy she is imposed new rules, new content, new dimensions and new knowledge. It is not possible to apply the previous paradigms of comparative advantages based on the available natural resources, labor and capital. The industrial age has been replaced by the postindustrial age age of the new economy, which is also known as the "age of knowledge". Today, the process of globalization is "downplayed world" and imposed new challenges in the process of creating and maintaining competitiveness. In fact, globalization has shaped the new business conditions which must be adjusted anyone who wants to be successful. She has specific requirements - constantly investing in knowledge, technology, research and development (Dedijer, 2013). Anyone who is lagging behind in the globalization process or it isn't included in the modern processes, significantly lagging behind.

Competitive advantage today is the basis for the success of any company in the global, highly competitive market. In modern economy foundations competitiveness are located in the high technologies, knowledge and innovation, global connectivity and strategic pooling. All companies, including the ones in the sphere of agriculture today are struggling to find such sources of competitive advantage, which will make better financial and other performance. The goal is to be better than others, and this can be achieved only by knowledge and innovation. The market value of every modern company consists of: 1.) The Financial Capital - "Tangible Assets" (means of production and money capital); 2.) Intellectual Capital - "Intangible Assets" (knowledge and skills of employees in the company, procedures, processes, organizational structure and relations with all stakeholders).

Competitive advantage of agricultural production today is based on intellectual capital (on knowledge, on abilities, on skills and innovation), on standards, on the design, on the patents, on the trademarks and brands (as forms of intellectual property rights) on the reputation, on the image, on the investing in research and development (innovation), as well as on overall (internal and external) relations, which can't be bought and are therefore a valuable source of competitive advantage.

Table 1. Sources of competitive advantage "Old Economy" vs. "Knowledge Economy"

\begin{tabular}{|c|c|}
\hline $\begin{array}{c}\text { SOURCES OF COMPETITIVE } \\
\text { ADVANTAGE IN THE"OLD ECONOMY" }\end{array}$ & $\begin{array}{l}\text { SOURCES OF COMPETITIVE ADVANTAGE } \\
\text { IN THE "KNOWLEDGE ECONOMY" }\end{array}$ \\
\hline $\begin{array}{l}\text { - Price } \\
\text { - Lower production costs } \\
\text { - Simple differentiation }\end{array}$ & $\begin{array}{l}\text { - Intellectual capital } \\
\text { - Intellectual property } \\
\text { - Image, identity, reputation } \\
\text { - Innovation, research, development } \\
\text { - Relations with stakeholders (internal / external) }\end{array}$ \\
\hline
\end{tabular}

Source: The table is the result of the autor's research 
So, in the new conditions the main goal is to also profit, but he creates in different ways: 1.) With the strategic planning; 2 .) Creating added value using the knowledge, using intellectual capital; 3.) By increasing the value of brand names; 4.) By protecting intellectual property rights and other relevant forms of intellectual capital; 5.) Using the internal knowledge and skills; 6.) By encouraging and supporting creativity and innovation of all employees, etc. From all the above it can be concluded that in the knowledge-based economy completely changed a way of creating value in companies.

History has shown and proved that every economic development was essentially determined by scientific and technological developments. In the course of historical development of human society has been changing role of science but also the role of man as the main drivers of change. "During the first scientific-technological revolution, man - worker was the main driver of change, and to produce important was the experience. The main role of science in this period was to analyze what happened and how something works. During the second scientific and technological revolution, the experience has been replaced by knowledge. At this stage, science is the driving force, and the bearer of development is man-expert.

Today, during the third scientific-technological revolution, the key to development is a science. Science is the leader, because the progress achieved by the results of scientific research" (Sundać, Švast, 2009).

From all the above it can be concluded that the economy of the 21 st century based on knowledge, or more precisely, on the intellectual capital. In a competitive global economy, where factors of production can be copied, people with their knowledge become the most important resource and a source of competitive advantage. The added value which is created in the business process derives primarily from the knowledge, abilities and skills of people working in the company or who cooperate with her. Investing in human capital is a key factor of value creation in modern business. As part of business and technical information, intellectual capital is often the only advantage over the competition. Therefore, every modern agricultural production can rely on the human intellect if he wants to reach high standards in today's highly competitive global market (Kolaković, 2003).

Although the intellectual property is very complex legal term, most generally can be said that it is ownership on the immaterial, intellectual possessions which are a result of human intellectual creativity. Today, many countries which have a highly developed agricultural production use own intellectual property in different ways, in order to improve own competitive position and achieve higher profits. Agricultural companies which own strengths and competitiveness based on intellectual property create herself the possibilities of exploiting of these resources and thus make a profit and competitive advantage in two ways (Porter, 2007): 1.) by implementation patented inventions into new products or production processes; 2.) by selling and licensing patented inventions to other companies and organizations. The Global Competitiveness reports published by the World Economic Forum the last few decades indicate to the correlation between protection of intellectual property rights and national competitiveness. 
About this topic will be discussed in the further course of this study. The examples from practice show that the new agricultural technology has the additional market value if it is protected by a patent, agricultural product is more valuable on the market if has a recognizable, registered trademark and among the many agricultural products consumers always prefer a product with an attractive industrial design which is legally protected from the imitation.

The process of globalization and all its effects led to the fact that it is intellectual property has become a powerful tool in today's business. "An efficient and equitable intellectual property system can help all countries to realize their own potential in the intellectual property as a powerful tool for economic development and social and cultural well-being... providing the an environment in which creativity and inventiveness can develop for the benefit of everyone. Intellectual property rights reward creativity and human mind, which are prerequisites advancement of humankind" (Intellectual Property Office of Serbia). In that context, it is of great importance education on the rights of intellectual property in the field of agricultural production, especially young people. In the near future they will become productive citizens who will by their own work, innovation and new knowledge to be able to contribute this branch of economy (Kristić, 2003).

The higher education institutions from this field must educate students about intellectual capital and intellectual property rights and their significance. It is very important because agricultural colleges are increasingly coming into contact with intellectual property, through the creation of inventions in research activities and transfers of technology.

Unfortunately, everyday examples from practice suggest that Serbia hasn't strategy for the development and application of knowledge in agricultural production. Although there are positive developments (mainly conditioned by the EU and other international institutions) in Serbia intellectual capital and intellectual property aren't sufficiently protected. This is especially evident in the irresponsible and indifferent relation with regard to protection of geographical indications and industrial designs of agricultural products. Also, the financial investment in science and scientific research are very small, almost insignificant. The result of such an attitude is a very small number of innovations and protected rights in the area of agricultural production and reduced incomes that could be achieved.

\section{Economic intelligence - a significant form of endangerment of intellectual capital in agricultural production}

In today's business conditions, knowledge has become the most important potential of each company and the development of information technology has contributed to the global economy more and more relies on intangible resources. The result is that the a man and his intellect became the center of the target of economic intelligence. "In today's international environment Economic espionage represents an instrument for achieving competitive advantages of the company, improving the national economy and the realization of national interests of each country" (Nešković, 2011). By applying legal 
and illegal methods which are often incompatible with the ethical standards of business, the goal is to eliminate competitors. The ultimate goal of economic intelligence is to get to business secrets. Activities of international economic intelligence are directed, primarily, to companies that are part of the national economy (Cvetković et al., 2008).

This kind of intelligencerepresents the sum of delicate, planned and professionally implemented activities on detecting classified information of competitors. Data that obtain this kind of intelligence are highly valuable because they reduce the costs of research and development, because it follows the technological development of a competitor without engaging a large number of experts and specialists. It is understood that the activities of economic intelligence are incompatible with the ethical and business standards, fair competition and regular economic competition. In global business conditions, intellectual capital and intellectual property of every successful agricultural companies have great value and everyone they want them for themselves. The intellectual capital of agriculture companies (knowledge, protected ideas, licences or patents) is often the target of economic intelligence.

Rapid changes that determine the process of globalization have caused big changes in the market. Traditionally agricultural markets replaced by a new market, which is dynamic, changeable and abundant with information. In those business conditions agricultural company must constantly scrutinize their competition and all around to find sources of competitive advantage. In today's world, every country or company who wants to take the global market of agricultural products has to rely on economic intelligence, because without it, is doomed to failure. This activity is an essential part of monitoring all developments on the world market and, also, must be a part of business strategy in domestic or foreign markets (Nešković, 2013). Regarding this, economic intelligence involves the collection, selection, processing and analysis of economic information on the markets for agricultural products, world agricultural exchanges, competitors, customers, competitive products etc.

Today's economic competitiveness became an economic warfare and a global phenomenon. This warfare represents the struggle for the placement agricultural products in abroad. Anglo-Saxons call it know-how and the French call it savoir-faire. Anyway, economic warfare aims to improve the national economy and overall national prosperity. It is obvious that each company in this field should protect and secure resources in the form of intellectual capital and intellectual property in order to conserve and enhance own businesses. Also, it is necessary to come into the possession of significant economic information and data, and convert them to economic knowledge - and thus achieve competitive advantage.

\section{Global Competitiveness Index (GCI)}

Global competitiveness of all the countries examines and evaluates the World Economic Forum (WEF) and its Global Competitiveness Index (GCI) which represent a set of institutions, policies and factors that together determine the level of productivity of a country. This index is based on twelve pillars of competitiveness, which are organized into three groups: Group I - Basic requirements; Group II - Factors 
that increase efficiency; Group III - Innovation and sophistication factors. Pillars include micro and macro economic factors and factors of development institutions, which together determine the competitiveness of a national economy. All data is evaluated on a scale from 1 to 7 ( 1 - the worst score, 7 - the best score). It is also the range of possible values for all indicators, pillars of competitiveness and GCI.

Table 2. Comparative overview of the global competitiveness report for $2013 / 14$ and $2014 / 15$

\begin{tabular}{|c|c|c|c|c|c|}
\hline $\begin{array}{l}2013 / 14 \\
148 \text { countries }\end{array}$ & Country & (GCI) & \begin{tabular}{|l|}
$2014 / 2015$ \\
144 countries
\end{tabular} & Country & (GCI) \\
\hline 1. & Switzerland & 5.7 & 1. & Switzerland & 5.7 \\
\hline 2. & Singapore & 5.6 & 2. & Singapore & 5.6 \\
\hline 3. & Finland & 5.5 & 3. & United States & 5.5 \\
\hline 4. & \begin{tabular}{|l|} 
Germany \\
\end{tabular} & 5.5 & 4. & Finland & 5.5 \\
\hline 5. & United States & 5.5 & 5. & Germany & 5.5 \\
\hline 6. & Sweden & 5.5 & 6. & Japan & 5.5 \\
\hline 7. & Hong Kong & 5.5 & 7. & Hong Kong & 5.5 \\
\hline 8. & Netherlands & 5.4 & 8. & Netherlands & 5.5 \\
\hline 9. & Japan & 5.4 & 9. & United Kingdom & 5.4 \\
\hline 10. & United Kingdom & 5.4 & 10. & Sweden & 5.4 \\
\hline ............... & .................... & $\ldots \ldots$ & ................. & ........................ & $\ldots \ldots .$. \\
\hline 101. & Serbia & 3.8 & 94. & Serbia & 3.9 \\
\hline$\ldots . .$. & ……............ & $\ldots \ldots$ & $\ldots .$. & …........... & $\ldots \ldots$. \\
\hline 148. & Chad & 2.9 & 144. & Guinea & 2.8 \\
\hline
\end{tabular}

Source: World Economic Forum, 20 and 21 (Read more on the: http://reports.weforum.org/ global-competitiveness-report-2014-2015/rankings)

According to the WEF report on global competitiveness for 2014/15 Serbia is at position 94 of the 144 countries that have entered into the analysis - with the value of GCI of 3.9 out of a possible 7 .

In contrast to the reports for the 2013/14 when in the analysis of the WEF were 148 countries and when Serbia took the 101 positions with a value of GCI of 3.8 out of a possible 7.

In comparison to the previous year, GCI value for Serbia is increased for 0.13, which resulted in to a positive displacement Serbia for 7 positions - from 101 to 94 positions on the list. 
Table 3. Global Competitivenesess Index (GCD) - Serbia

Global Competitivenesess Index (GCI) Serbia

$$
\text { Rank Score }
$$

GCI 2011-2012

(out of 142)

GCI 2012-2013

(out of 144)

GCI 2013-2014

(out of 148)

95
$\quad 3.9$

$95 \quad 3.9$

$101 \quad 3.8$

GCI 2014-2015

$94 \quad 3.9$

Rank Score

(out of 144) (1-7)

\section{Basic requirements}

$\begin{array}{lll}\mathbf{( 4 0 . 0 \% )} & \mathbf{1 0 1} & \mathbf{4 . 1} \\ \text { Institutions } & 122 & 3.2 \\ \text { Infrastructure } & 77 & 3.9 \\ \text { Makroec. environment } & 129 & 3.5 \\ \text { Health and primary educ. } & 68 & 5.8\end{array}$

\section{Efficiency enhancers}

$(50.0 \%)$

$80 \quad 3.9$

Higher educ. and training $74 \quad 4.3$

$\begin{array}{lll}\text { Goods market efficiency } \quad 128 \quad 3.8 & 3.9\end{array}$

$\begin{array}{lll}\text { Labor market develop. } \quad 119 & 3.7\end{array}$

Financial market develop. $109 \quad 3.5$

Tehnological readiness $\quad 49 \quad 4.4$

Market size

$\begin{array}{ll}71 & 3.7\end{array}$

\section{Innovation and}

$\begin{array}{lll}\text { sophistication factors } & 121 & 3.1\end{array}$

$\begin{array}{lll}\text { Business sophistication } \quad 132 \quad 3.2 & \text {. }\end{array}$

$\begin{array}{lll}\text { Innovation } & 108 & 2.0\end{array}$

Source: World Economic Forum [23]
Figure 1. Stage of development - Serbia vs. Europe

Stage of development

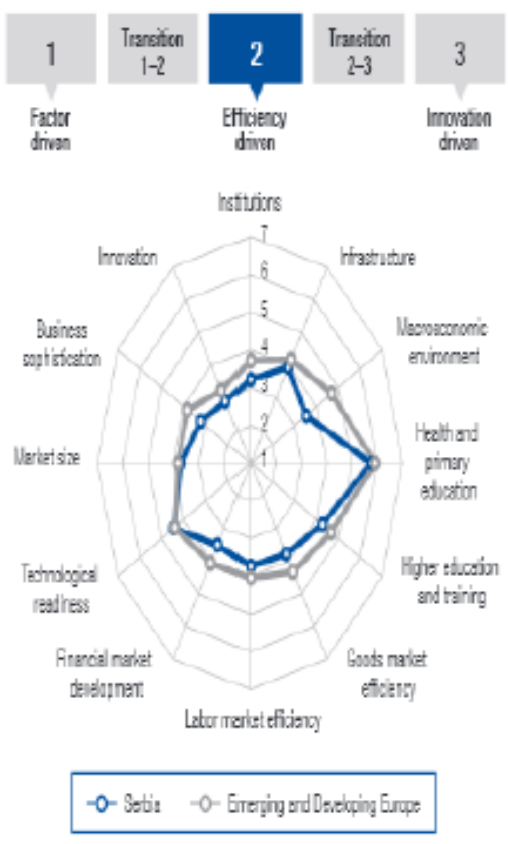

Source: World Economic Forum [23] 
Table 4. The Global Competitiveness Index in detail

\begin{tabular}{|c|c|c|}
\hline INICATOR & $(1-7)$ & RAIK/14 \\
\hline \multicolumn{3}{|l|}{ lst pillar. INSTIIUTION } \\
\hline 1.01 Property rights & 3.1 & \\
\hline 1.02 Intellectual property protection & & \\
\hline 1.03 Diversion of public finds 27 & 99 & \\
\hline 1.04 Public tust in politicions 21 & 118 & \\
\hline 1.05 Inegular paymerts and tribes & 39 & $\theta$ \\
\hline 1.06 Juxicul independence & 2 & \\
\hline 1.07 Fanoritisms in decisions of goverm & 2. & \\
\hline 1.08 Wastefiumess of gov. spenting & & \\
\hline 1.09 Burden of gov. reguhtion 2.2 & 140 & \\
\hline 1.10 Efficiency of $\mathrm{kg}$ finm in sett dispures & & 1 \\
\hline 1.11 Efric of lez finm in challene regs & 2 & \\
\hline 1.12 Transpurenc. of gov. policyunking & 3.6 & \\
\hline 1.13 Business cost of tarisum 55 & 58 & \\
\hline 1.14 Business costs of crime and violence & 42 & \\
\hline 1.15 Orgnnized crime & 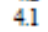 & \\
\hline 1.16 Reliability of police services & 3. & \\
\hline 1.17 Ethical bahavior of firms 3.4 & 119 & \\
\hline 1.18 Streng of auding and reporting stand & 109 & \\
\hline 1.19 Efficacy of componte boards & 3.8 & \\
\hline 1.20 Protect of minar. shareholders int & & \\
\hline 1.21 Stumait of invest. protection & 5 & \\
\hline
\end{tabular}

\begin{tabular}{|c|c|c|}
\hline \multicolumn{3}{|l|}{ 2nd pillor. IFRASTRUCTURE } \\
\hline 2.01 Qality of ovenll infinstructure & 3.3 & 111 \\
\hline 2.02 Quality of roxds & & 114 \\
\hline 2.03 Quality of raitroad infinstructure & & 83 \\
\hline 2.04 Quality of port infinstructure & & 127 \\
\hline 2.05 Quality of air transport infinstuat. & & 112 \\
\hline .06 Available airline sent & 74.0 & 03 \\
\hline .07 Qualitu of electricity supply & & \\
\hline 108 Mobile tel subscriptions 100 pop & 119.4 & \\
\hline 2.09 Fived telephone line 100 pop & 39.3 & $\underline{6}$ \\
\hline
\end{tabular}

\section{3rd pillar. MACROECONOMIC ENVIRONMIENT}

3.01 Gov budget balarce \% GDP

3.02 Gross national savings \% GDP $\quad 11.5$

3.03 Infation, armal \% change $7.7 \quad 124$

3.04 Generl government deix, \% GDP $\quad 65,8 \quad 108$

3.05 county cealit nting $0-100 \quad 32.5 \quad 81$

\section{4th pillar. HEALTH AND PRMMARY EDUCATION}

4.01 Maluria cases/100000 pop. MF

4.02 Business impact of maluria $\mathrm{N}$

4.03 Tuberculosis cases 100000 pop

4.04 Business impact of tuberculosis

$4.05 \mathrm{HIV}$ prevalence, $\%$ adut pop.

4.06 Business impact of HIV/AIDS

4.07 Infint mortiliry, deaths/ 1000 live biths

4.08L ife expectancy, years

4.09 Quality of priming echacation.

4.10 Primary eatic enrolment, ns $\%$

\begin{tabular}{lll} 
n & & \\
n & & \\
23.0 & & 50 \\
6.4 & & 31 \\
0.1 & & 1 \\
6.5 & & 14 \\
5.7 & & 37 \\
75.2 & 52 \\
3.8 & 78 \\
91.4 & 94 \\
\hline
\end{tabular}

Sth pillar. HICHER EDUCATIONAND TRAINTNG

5.01 Second ectucation enrolment, gros5 \% 91.7

5.02 Tertiary education enrolment, gros $\%$

5.03 Quality of the edacarion system

5.04 Quality of muth and science education

5.05 Quality of mangement schools

5.06 Intengt access in schools 42

5.07 Availab. of resemch and training $5 a v$.

5.08 Evtent of staff training

\section{4}

3.1

4.3
3.6

3.6

72

3.5

3.1

108

6th pillar COODSMARKET EBICIFNCY

6.01 Intensity of bakoupetion 4

6.02 Evtent of

6.03Efectiv of anti-Inonopoly policy

6.04 Efectiv. of tax on incerives to imest

6.05 Total taxinte, \% profils

3

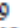

118

132

128

129

86

89

125

68

1

114

127

112

16

C




\section{Results and discussion}

In Table 4. is presented Global Competitiveness Index in detail Serbia - for 2014/15, by the World Economic Forum. For this research the most important are data from the first, sixth, ninth, eleventh and twelfth pillar which are specially marked.

In the 1st pillar it is clear that Serbia has an extremely low level of intellectual property protection, which was rated very low - only 2.9 out of a possible 7 . With this result, our country is located on the 113th position from 144 countries which were included in this study.

The cost of agricultural policy presented in the 6th pillar also rated low - only 3 out of a possible 7. This rating put Serbia on 128th position of 144 countries. Such a low rating proves that Serbian agriculture does business with extremely high costs - which is the consequence of inefficient use of their own intellectual resources and the absence of closer cooperation between academic and research institutes and agricultural production. The result of this situation is high percentage of imports of knowledge, of agricultural technologies, of patents and licenses.

The 9th pillar of the GCI, which includes the availability of modern technology and the ability to absorbed technology - also shows very unsatisfactory results. The availability of modern technology was evaluated by 4.2 out of a possible 7 , which puts our country on 106th position of 144 countries. The companies' absorptions of technology are evaluated by 3.8 out of a possible 7 . Under this criterion Serbia is located on 127 th position out of 144 countries.

The nature of competitive advantages in the pillar 11 is evaluated with 2.4 out of a possible 7 and on this issue Serbia is located on a very bad position (141 out of 144 countries). This result shows the source of our competitive advantages. It's cheap labor rather than skilled labor.

12th pillar which encompasses the area of innovation, also shows very low ratings. The pride of this pillar are only scientists and their institutions, which are the starting point in any research process. For this reason, every country which aims to achieve a competitive advantage should invest significant funds in science and research.

The data in Table 4. show that in a globalized business environment sustainable growth and global competitiveness can't be achieved without the export of knowledge, intellectual capital, intellectual property, innovation and technology. According to the WEF report for 2014/15 Serbia occupies the 94 position out of 144 countries with very low marks on innovation and business sophistication. ${ }^{4}$ The results achieved in the field of intellectual property, technology, agriculture, nature of competitive advantages and innovation, which are presented in the detailed view of the GCI for 2014/15 in the 1st, 6th, 9th, 11th and 12th pillar ${ }^{5}$, clearly show that in the Serbian economy has a few innovative products and

$4 \quad$ See table 3 on page 10 .

5 See table 4 on page 11.

EP 2016 (63) 2 (445-459) 
processes. All of the aforementioned leads to a conclusion that Serbia evidently has a significant intellectual resources. However, the impression is that the to these resources is managed by ad hoc, rather than with the strategy. Our current exports are mostly based on price-competition, investment in new equipment, technology and human resources are almost do not exist. If Serbian companies want to develop new products and services and to achieve economic growth and international competitiveness, it is necessary to increase investment in intellectual capital and new technologies.

\section{Conclusions}

Modern global market is based on a completely new competition rules, which resulted in changes in the strategies of companies and countries. In order to create and improve competitiveness, today is clearly accentuated orientation of investment in intangible assets. Science and technology are now built into the foundations of any modern society and all aspects of human life. A very fast scientific and technological progress and development in the sphere of information technologies, stand out to the forefront the importance of intellectual capital. Today, human capital is a key factor for improving the competitiveness of the national agriculture. Very often this capital reaches up to $90 \%$ of the companies, which is a confirmation that human knowledge and skills are crucial for a positive competitive position.

Protection of intellectual property in the field of agricultural production represents a very important part of the strategy of competitiveness (http://www.madmarx.rs). The safest way of protection these values is the registration with relevant institutions, which guarantees the protection of intellectual property rights. It will prevent the competition that easily copies the new agricultural product or service. Trade secrets and specific knowledge, can also be protected through confidentiality agreements and contracts with employees. Licensing of their own intellectual property to others can be a good way of gaining profit and for expanding their own business models with small efforts and at low risk.

Also, through a similar arrangement, can be obtained the right to use the intellectual property of others, which can help to expand and improve the quality of agricultural production without large investments - which confirms the auxiliary hypotheses $\mathrm{H} 2$ and $\mathrm{H} 3$ presented on page 4.

In the global business environment, economic competitiveness has become an economic warfare and economic intelligence is the primary means of stealing intellectual resources. This form of jeopardizing of business significantly increases the power of new technologies, knowledge and timely possession of important business information. The targets are most often trade secrets, the specific knowledge and intellectual property that is protected by patent rights. This form of intelligence very often doesn't respect the rules and standards of ethics but collects the data and information by illegal means, and after the analysis turns them into a competitive knowledge.

Changes in the globalized, highly competitive world caused the weakening of the comparative advantages of the agrarian sector of Serbia (Đekić, 2005). Although we have 
quantity of resources, it is not our competitive advantage compared to the international environment. So, our advantage could be the quality of knowledge embedded into agricultural product and/or service. But, in order to improve the quality of knowledge it is necessary to create an education system that supports the innovative thinking. Improved education system will increase the number of own original agricultural products, processes and technologies, which would increase the global competitiveness of Serbia. At the same time, it is necessary to bridge the huge gap that exists in Serbia between science, research and development sector and agricultural production. For Serbian agribusiness is of utmost importance to stimulate and develops its own intellectual capital because this will enable the more efficient utilization of the physical capital and increasing of financial capital. Only in this way a source of competitive advantages of Serbia will not be cheap labor, but the knowledge, expertise and ability.

In the end, it can be concluded that the global competitiveness can realize only companies and countries which recognize the value of their own knowledge, timely identify the threats and efficiently to protect its own material and intellectual values. This fact prove the most powerful agricultural companies which have become the strongest pillars of their own national economies thanks to patented and protected innovations based on intellectual capital. Countries with these kinds of companies are the leaders in the global market of agricultural products. Also, these countries are at the top of countries according to WEF's Global Competitiveness Index, which confirms the hypothesis H1.

\section{Literature}

1. Cvetković, N., Grk, S., Vidas-Bubanja M. (2008): Tranzicioni izazovi agroprivrede Srbije u kontekstu međunarodnih integracija, Ekonomika Poljoprivrede, vol. 55, no. 3, pp. 237-251 Beograd

2. Dedijer, S. (2003): Development \& Intelligence 2003-2053, (No. 2003/10).

3. Đekić ,S. (2005): Agrarni menadžment, Ekonomski fakultet, Niš

4. Jovanović, S., Dragutinović, S., Petrović, D.S. (2010): Značaj vrednovanja i eksploatacije intelektualne svojine, Industrija, vol. 38, no. 4, pp. 13-28.

5. Jovanović, S., Matović, D., Petrović, D.S. (2011): Vrednovanje intelektualne svojine, Industrija, vol. 39, no.2, pp. 93-117.

6. Kolaković, M., (2003): Teorija intelektualnog kapitala, Ekonomski pregled, vol. 54, no. 11-12, pp. 925-944 (available at: hrcak.srce.hr/file/40500).

7. Kristić, B. (2004): Uticaj inovacija znanja, proizvoda i procesa na efikasnost preduzeća, Poslovna politika, Septembar, Beograd

8. Marić, V. (2013): Zaštita intelektualne svojine u Srbiji (available at: http://www. madmarx.rs).

9. Nešković, S. (2011). Ekonomska špijunaža u savremenoj međunarodnoj konstelaciji, Ekonomija teorija i praksa, vol. 4, no. 1, pp. 111-127.

10. Nešković, S. (2013): Ekonomska špijunaža i nove tehnologije u globalizovanoj

EP 2016 (63) 2 (445-459) 
međunarodnoj zajednici, Vojno delo, vol. 65, no. 2, pp. 57-76.

11. Porter, M. E. (2007): Konkurentska prednost: ostvarivanje $i$ očuvanje vrhunskih poslovnih rezultata, prevod: Mira i Vera Gligorijević, Asee; Graph style, Novi Sad

12. Petrović, Z. P. (2005): Ekonomska špijunaža: mali vodič kroz istoriju ekonomske obaveštajnosti, do Desete revolucije čovečanstva, Beograd, Draslar partner - Centar Jugoistok - Institut za političke studije

13. Skandia, Intellectual Capital-Value Creating Processes, a supplement to Skandia's 1995 Annual Report, page 5 (available at: http://www.exinfm.com/training/pdffiles/case_study_ skandia.pdf).

14. Sullivan, P. (2000): Value-driven Intellectual Capital; How to convert Intangible Corporate Assets into Market Value (available at: http://www.sveiby.com/articles/ icmmovement.htm).

15. Sundać, D., Švast, N. (2009): Intelektualni kapital - temeljni čimbenik konkurentnosti poduzeća, Ministarstvo gospodarstva, rada i poduzetništva, Zagreb (availableat:http:// eobrazovanje.mingorp.hr/UserDocsImages/Knjizica_intelektualni_kapital.pdf).

16. Stewart, A. (1997): Intellectual Capital - The New Wealth of Organizations, Doubleday, New York

17. Steven, A., Bradley, K. (1995): The Management if Intellectual Capital, unpublished monograph, The Buseness Performanse Group Limited, London

18. Zindović, I. (2008): Multinacionalne kompanije i ekonomska špijunaža, Alisa Press, Kraljevo

19. Šta je intelektualna svojina? (available at: http:/www.zis.gov.rs/upload/documents/ pdf_sr/pdf/sta_je_intelektualna_svojina.pdf).

20. WEF global competitiveness report for 2013/14 (available at: http:/www3.weforum. org/docs/WEF_GlobalCompetitivenessReport_2013-14.pdf, p.16, date of accession 4.03.2015).

21 WEF global competitiveness report for 2014/2015 (available at :http://reports.weforum. org/global-competitiveness-report-2014-2015/rankings/, date of accession 4.03.2015).

22. The Global Competitiveness Index in detail - Serbia (available at: http://www3. weforum.org/docs/GCR2014-15/Serbia pdf, p. 329, date of accession 5.03.2015).

23. Global Competitiveness Index (GCI) - Serbia (available at: http://www3.weforum.org/ docs/GCR2014-15/Serbia.pdf, p. 328, date of accession 5.03.2015). 


\title{
EKONOMSKA ŠPIJUNAŽA I INTELEKTUALNI KAPITAL U KONKURENTNOSTI POLJOPRIVREDE-STUDIJA SLUČAJA
}

\author{
Slobodan Neškovićc ${ }^{6}$ Žaklina Jovanovićc Miroslav Čavlin ${ }^{8}$
}

\begin{abstract}
Sažetak
Pod uticajem procesa globalizacije u poslednjih nekoliko desetina godina došlo je do niza tehnoloških, privrednih $i$ društvenih promena, koje su transformisale svetsko tržište poljoprivrednih proizvoda $i$ uticale na konkurentsko okruženje. U savremenom svetu stvaranje materijalnih vrednosti u poljoprivrednoj proizvodnji sve više je rezultat nematerijalnih faktora, tj. proizvodnja se sve više temelji na znanju, sposobnosti $i$ inovativnostizaposlenih. Uindustrijskom dobuneophodniresursiza postizanjekonkurentske prednosti bili su kapital, prirodni resursi i rad, dok se u današnjoj ekonomiji zasnovanoj na znanju ta značajnost pomera ka informacijama, inovacijama i znanju, tj. intelektualnom kapitalu i intelektualnoj svojini - koji su postali temelj kreiranja svih drugih vrednosti. Navedene vrednosti su, zbog svog velikog značaja u ostvarivanju savremene konkurentske prednosti, vrlo često meta ekonomske špijunaže i zbog toga zahtevaju sve raspoložive oblike zaštićenosti. Sektor poljoprivredne proizvodnje može dati značajan doprinos unapređenju celokupne nacionalne konkurentnosti ako se zasniva na intelektualnom kapitalu, što dokazuju zemlje sa visoko razvijenom poljoprivrednom proizvodnjom. Međutim, kada se sagledaju globalne promene može se zaključiti da Srbija u ovom sektoru ima neiskorišćen potencijal za rast i razvoj.
\end{abstract}

Ključne reči: konkurentnost, intelektualni kapital, intelektualna svojina, poljoprivredna proizvodnja, ekonomska špijunaža

6 Redovni profesor, dr Slobodan Nešković, Fakultet za ekonomiju i inženjerski menadžment u Novom Sadu, Ulica Cvećarska br. 2, 21000 Novi Sad, Srbija, Telefon: +381 63391659 , E-mail: slobneskovic@gmail.com

7 Master Žaklina Jovanović, Saradnik u naučnom udruženju Centar za strateška istraživanja nacionalne bezbednosti CESNA B, Ulica Vojvode Vlahovića br. 35d/1.2, Beograd, Srbija, +381635313 93, E-mail: zaklinajovanovic.021@gmail.com

8 Vanredni profesor, dr Miroslav Čavlin, Univerzitet Privredna Akademija Novi Sad, FIMEK, Cvećarska ulica br. 2, 21000 Novi Sad, Srbija, Telefon: +381 21400 484, E-mail: cmiros@gmail.com

EP 2016 (63) 2 (445-459) 